\title{
Measurement of Effective Thermal Conductivity of Cupra and Polyester Fiber Assemblies in Low Fiber Volume Fraction
}

\author{
Yoneda Morihiro $^{\mathrm{a}, *}$, NAKAJIMa Chie ${ }^{\mathrm{b}}$ \\ ${ }^{a}$ Faculty of Human Life and Environment, Nara Women's University, Kitauoya-Nishimachi, Nara 630-8506, Japan \\ ${ }^{\mathrm{b}}$ Graduate School of Human Culture, Nara Women's University, Kitauoya-Nishimachi, Nara 630-8506, Japan
}

Received 16 August 2015; accepted for publication 16 June 2016

\begin{abstract}
In this study, the effective thermal conductivity of Cupra, Polyester and Polytrimethyleneterephthalate (PTT) fiber assemblies in low fiber volume fraction is measured using KES-F7 Thermo Labo II apparatus. In order to eliminate thermal perturbation by external heat, the radiation shielding board is set up between samples and operator. Heat flux to calculate thermal conductivity is measured including heat leakage from the side wall of sample and is calibrated in the analysis. The results are analyzed using non-linear regression method. The results are obtained as follows. Thermal conductivity curve is convex downward within the range of fiber volume fraction measured. The effective thermal conductivity, $\lambda$ is expressed as following equation, $\lambda=\mathrm{A} \varphi+\mathrm{B} / \varphi+\mathrm{C}$ where, $\varphi$ : fiber volume fraction, $\mathrm{A}$, $\mathrm{B}$ : coefficients and $\mathrm{C}$ : constant determined by non-linear regression analysis. Based on this equation, the effective thermal conductivity is divided into three parts, i.e. A $\varphi$ : heat conduction within fiber, $\mathrm{B} / \varphi$ : radiative heat transfer and $\mathrm{C}$ : heat conduction within air. Component of conduction in air, $\mathrm{C}$ plays a most important role in thermal conductivity of fiber assembly, and component of heat conduction in fiber, $\mathrm{A} \varphi$ follows in higher fiber volume fraction.
\end{abstract}

Key Words : Effective thermal conductivity, Fiber assembly, Cupra fiber, Polyester fiber, Non-linear regression

\author{
低体積分率に扮けるキュプラ・ポリエステル短繊維集合体の \\ 有効熱伝導率の測定 \\ 米田守宏 ${ }^{\mathrm{a}, *}$, 中島千恵 ${ }^{\mathrm{b}}$ \\ a 奈良女子大学生活環境学部, ${ }^{b}$ 奈良女子大学大学院人間文化研究科
}

\section{1. 緒 言}

寝具用充填材料においては, 天然繊維および化学繊維など からなる低い体積分率の短繊維集合体が使用されている。こ れら短繊維集合体の熱伝導性は, 主に有効熱伝導率によって 評価される。一般に, 布帛や繊維集合体などの有効熱伝導率 の評価法としては, 平行平板法を用い, 定常状態において, 高温側から低温側へ向けて試料を通して流れる熱流束を測定 する方法が用いられている。

これまで, 緎維集合体の熱伝導に関する研究としては, ポ リエステル繊維集合体の伝熱機構に関する理論的および実験
的研究 $[1,2]$, および防寒用被服材料あるいは繊維質断熱材 などの有効熱伝導率に関する研究 $[3,5]$ などが報告されてい る、いずれの研究においても, 低い体積分率（10\%以下）の 繊維集合体における有効熱伝導率対繊維体積分率の関係は, 下に凸な曲線形状を示すことが明らかにされている。このよ うに，低繊維体積分率において有効熱伝導率が極小を持つこ とは, これまで繊維集合体が断熱材料として広く用いられて きたことに対する大きな理由である。 さらに, 有効熱伝導率 が低体積分率において極小をもつ理由は, 空隙率の増加に伴 い空間を伝播する輻射伝熱成分が増加するためであること が，それぞれの伝熱モデルおよび測定結果により示されてい

* 連絡先：奈良女子大学 生活環境学部 630-8506 奈良市北魚屋西町 E-mail : yoneda@cc.nara-wu.ac.jp, Tel/Fax : +81-742-20-3463 
る。野飼らの場合は $[1,2]$, 一軸配向繊維集合体モデルにお いて繊維伝導成分および輻射伝熱成分を考慮することにより 導いている。藤本らは [3]，繊維部と空隙部からなる熱流の 直列－並列モデルに輻射伝熱項を取り入れたモデルに基づい て考察を行っている.

本研究では，これまでの繊維集合体の有効熱伝導率の研究 [1-3］を受けて，現在市場で流通しているキュプラ短繊維， ポリエステル短繊維およびポリトリメチレンテレフタレート 短繊維からなる繊維集合体の有効熱伝導率の検討を行う。本 研究では, 簡易で標準的な測定法の実現および解析の容易さ を考慮して, 以下の点について留意した。（1）試料として実 用的に使用されることの多いランダム配向繊維集合体を取り 上げた。（2）試料のハンドリングを容易にするため，比較的 単純な構造を持つ試料充填用フレームを採用した。（3）数式 モデルとして，建築用繊維質断熱材料の分野で用いられてい る非線形回帰モデルを採用した。

本研究で取り扱う低体積分率の短繊維集合体の性状および 熱的な特性は次の通りである。組成の特徴としては, ごくわ ずかな繊維（体積にして $3 \%$ 以下）の他はほとんどが空気か らなっている。このため, 試料の熱容量が小さく, 対流によ る熱的な擾乱も受けやすい. したがって，測定系が備えてい る熱源以外に熱源に相当するものが存在する場合, 試料系へ 容易に熱が流入するおそれがある。さらに，測定に際して不 定形の試料を一定の形状に整えるため, 測定用試料枠の使用 が不可欠であるが, この場合, 枠を通しての熱の漏れが予想 される，以上のように，本研究で対象としている試料系は熱 物性の測定を精度よく行うには不利な条件をいくつか備えて いる。このような試料系の熱的な特徵を考慮に入れて, 熱源 以外からの測定装置一試料系への熱の流入を極力排除し， あ わせて, 試料枠からの熱の漏れ量の校正が可能になるよう, 測定系および測定方法に配慮しながら熱伝導率の測定を実施 した。

本論文では，低体積分率の短繊維集合体の有効熱伝導率の 測定を次のように行った。予備実験として測定者（人体）の 輻射熱が繊維集合体の有効熱伝導率測定に及ぼす影響につい
て明らかにするため，測定部分と測定者の間に輻射熱を遮る 板（以下，輻射熱ガード板と呼ぶ）を設置する場合と設置し ない場合での有効熱伝導率測定值の比較・検討を行った。 こ のような予備実験の結果を踏まえて, 本実験ではヒートシン クとしてペルチェ素子冷却装置を用い，輻射熱ガード板を設 置するという条件の下で，上記繊維集合体の有効熱伝導率を 測定した。測定結果を整理するため, 建築用繊維質断熱材の 性能評価に利用されている高密度対有効熱伝導率の実験式を 採用して，有効熱伝導率に関して検討した。非線形回帰分析 の手法を用いて, 得られた有効熱伝導率を繊維伝導成分, 輻 射成分，ガス伝導成分および熱の漏れ成分の分離を試みた。 以下に，検討の結果について報告する．

\section{2. 実 験}

\section{1 試料}

本実験に使用した短繊維材料は, 繊度と繊維長をほぼ等し くした繊度 $1.4 \mathrm{dtex}$ ・䋊維長 $38 \mathrm{~mm}$ のキュプラ $(\mathrm{CU})$, 繊度 $1.3 \mathrm{dtex}$ ・繊維長 $38 \mathrm{~mm}$ の丸断面ポリエステル (RPE), 繊度 $1.4 \mathrm{dtex}$ ・繊維長 $38 \mathrm{~mm}$ の異型断面ポリエステル (WPE), お よび, 繊度 $1.7 \mathrm{dtex}$ ・䋊維長 $51 \mathrm{~mm}$ のポリトリメチレンテレ フタレート (PTT) の計 4 種である。これらの原綿を開繊し， カーディングしたウェブを用い, 恒温恒湿室における $20 \pm$ $2{ }^{\circ} \mathrm{C}, 65 \pm 2 \% \mathrm{RH}$ の環境条件下で 24 時間以上調湿した後に実 験に供した。これら試料の性状を Table 1 に示す.

繊維集合体における有効熱伝導率の主要な測定条件として 体積分率がある。ここで素材ごとの体積分率をほぼ等しくし， 繊維の分布が一様になるように，素材によって必要な試料重 量をあらかじめ設定した。体積分率は繊維集合体の見掛けの 体積に対する繊維の実体積の割合であり，以下のようにして 求めた。本研究においては四角柱状試料を使用したため, 試 料重量を $\mathrm{W}(\mathrm{g})$, 繊維の比重を $\rho$ (n.d.), 一辺の長さを $\mathrm{h}(\mathrm{cm})$, 試料の厚さを $\mathrm{d}(\mathrm{cm})$ とすると, 体積分率 $\varphi($ n.d $)$ は,

Table 1 Details of fiber samples for wadding use.

\begin{tabular}{|c|c|c|c|c|c|c|}
\hline $\begin{array}{l}\text { Sample } \\
\text { code }\end{array}$ & Detail of sample & $\begin{array}{l}\text { Fineness } \\
\text { (dtex) }\end{array}$ & $\begin{array}{l}\text { Fiber } \\
\text { length } \\
(\mathrm{mm})\end{array}$ & $\begin{array}{c}\text { Fiber } \\
\text { diameter } \\
(\mu \mathrm{m})\end{array}$ & $\begin{array}{l}\text { Specific } \\
\text { gravity } \\
\text { (n.d.) }\end{array}$ & $\begin{array}{l}\text { Percentage } \\
\text { of crimp } \\
(\%)\end{array}$ \\
\hline $\mathrm{CU}$ & $\begin{array}{l}\text { Cupra-ammonium (Cupra) } \\
\text { staple fiber }\end{array}$ & 1.4 & 38 & 11.84 & 1.50 & 8.79 \\
\hline RPE & $\begin{array}{l}\text { Polyester staple fiber with } \\
\text { round section }\end{array}$ & 1.3 & 38 & 12.76 & 1.38 & 26.70 \\
\hline \multirow{2}{*}{ WPE } & \multirow{2}{*}{$\begin{array}{l}\text { Polyester staple fiber with } \\
\text { W-shaped heteromorphic section }\end{array}$} & \multirow{2}{*}{1.4} & \multirow{2}{*}{38} & $24.22^{* 1}$ & \multirow{2}{*}{1.38} & \multirow{2}{*}{14.80} \\
\hline & & & & $6.27^{* 2}$ & & \\
\hline PTT & $\begin{array}{l}\text { Polytrimethyleneterephtalate staple } \\
\text { fiber }\end{array}$ & 1.7 & 51 & 15.02 & 1.34 & 15.43 \\
\hline
\end{tabular}

*1: a major-axis, $* 2$ : a minor-axis 


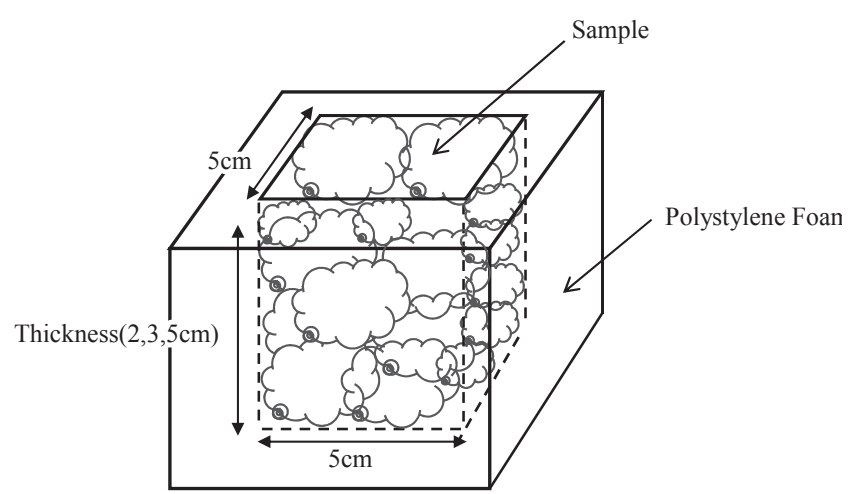

Fig. 1 Schematic diagram of filling fiber sample into frame made of polystylene foam.

$$
\varphi=\frac{W}{\rho d h^{2}}
$$

で表される。この一定量の短繊維材料を, 有効測定面積 $25 \mathrm{~cm}^{2}$ (一辺の長さ $5 \mathrm{~cm}$ )，高さがそれぞれ $2,3,5 \mathrm{~cm}$ の発泡ス チロール製の四角柱状試料充填枠の中にできるだけ均一にな るように，ピンセットを使用して充填したものを実験試料と した。

輻射熱環境の影響を検討するための予備実験は，CU およ びポリエステル系の代表としてRPEの 2 種の試料を用いて 行った。体積分率は 0.010 , 試料の厚さを $5 \mathrm{~cm}$ とした。試料 充填用断熱枠に試料を充填した様子を Fig. 1 に, 試料充填用 断熱杂の平面図を Fig.2 に示す。 CU の試料重量は $1.9 \mathrm{~g}, \mathrm{RPE}$ の試料重量は $1.7 \mathrm{~g}$ である.

有効熱伝導率の測定に関する本実験に使用した短繊維材料 はCU, RPE, WPE, PTT の計 4 種である。本実験では繊維 体積分率および試料厚さに関して熱伝導特性を調べるため, 繊維体積分率は， $0.001 ， 0.005 ， 0.010 ， 0.025 ， 0.030$ の 5 条 件, 試料の厚さを $2 \mathrm{~cm}, 3 \mathrm{~cm}, 5 \mathrm{~cm}$ の 3 条件とし, 試料 1 種 につき計 15 条件の測定を行った，各試料（CU, RPE, WPE,

(a)

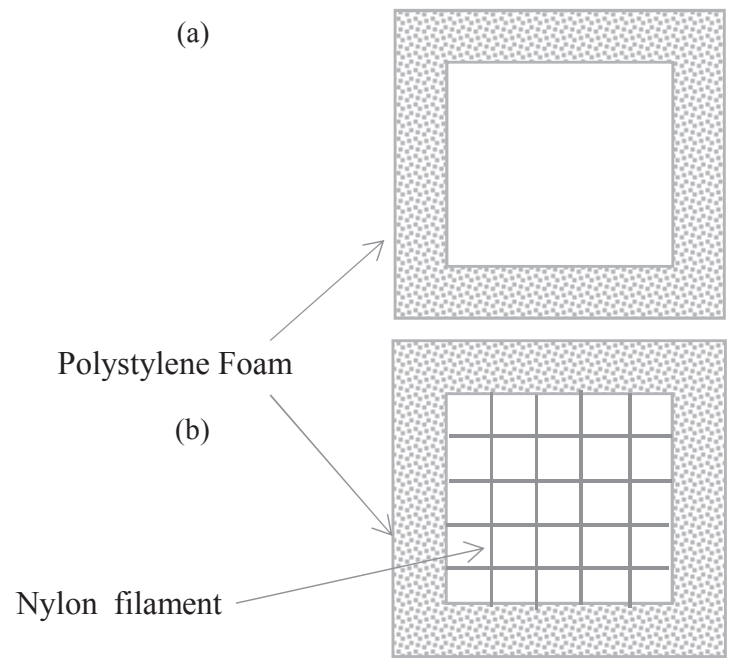

Fig. 2 Frame made of polystylene foam (a) Top view (b) Bottom view.
Table 2 Sample weight for each measurement condition. (unit: g)

\begin{tabular}{|c|c|c|c|c|}
\hline \multirow{2}{*}{ Sample } & \multirow{2}{*}{ Volume fraction } & \multicolumn{3}{|c|}{ Thickness of a sample } \\
\cline { 2 - 5 } & & $2 \mathrm{~cm}$ & $3 \mathrm{~cm}$ & $5 \mathrm{~cm}$ \\
\hline \multirow{4}{*}{ Cupra } & 0.001 & 0.075 & 0.113 & 0.188 \\
\cline { 2 - 5 } & 0.005 & 0.375 & 0.563 & 0.938 \\
\cline { 2 - 5 } & 0.010 & 0.750 & 1.125 & 1.875 \\
\cline { 2 - 5 } & 0.025 & 1.875 & 2.813 & 4.688 \\
\cline { 2 - 5 } & 0.030 & 2.250 & 3.375 & 5.625 \\
\hline \multirow{4}{*}{ Polyester } & 0.001 & 0.069 & 0.104 & 0.173 \\
\cline { 2 - 5 } & 0.005 & 0.345 & 0.518 & 0.863 \\
\cline { 2 - 5 } & 0.010 & 0.690 & 1.035 & 1.725 \\
\cline { 2 - 5 } & 0.025 & 1.725 & 2.588 & 4.313 \\
\hline \multirow{5}{*}{ PTT } & 0.030 & 2.070 & 3.105 & 5.175 \\
\cline { 2 - 5 } & 0.001 & 0.067 & 0.101 & 0.168 \\
\cline { 2 - 5 } & 0.005 & 0.335 & 0.503 & 0.838 \\
\cline { 2 - 5 } & 0.010 & 0.670 & 1.005 & 1.675 \\
\cline { 2 - 5 } & 0.025 & 1.675 & 2.513 & 4.188 \\
\hline
\end{tabular}

PTT）の試料重量を Table 2 に示す.

\section{2 実験装置および実験方法}

有効熱伝導率の測定はサーモラボ II 型試験機（珠)カー テック製 KES-F7）を用いて行った [4]。平行平板法により， 定常状態において高温側熱源（BT-Box）から低温側（ヒート シンク）へ向けて試料を介して流れる熱流量を測定する。測 定部分（断面図）の模式図を Fig.3に示す。試料である繊維 集合体を一定の厚さの発泡スチロール製の枠内に一様に充填 した状態で熱移動の測定を行う。実験は $20 \pm 2^{\circ} \mathrm{C} ， 65 \pm 2 \% \mathrm{RH}$ の環境条件下で行った.

高温側の BT-Box の設定温度を $30^{\circ} \mathrm{C}$, 低温側のヒートシン

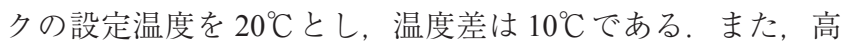
温側を上面とし，低温側を下面に設定し，測定される熱流量 の熱流の方向は重力の向きと一致させた. ヒートシンクとし てペルチェ素子冷却装置サーモクール（以下，冷却ベースと 呼ぶ）を使用した。冷却ベースでは熱電半導体の一種である ペルチェ素子を利用した冷却装置により試料下面を温度一定 に保つ、ペルチェ効果を利用して冷却を行うため, モーター, ファンなどの可動要素が不要であるという特徴を持つ。試料 充填用断熱染は 1 試行終了ごとに，20ㄷ に設定したペルチェ 素子冷却装置上に置く。このような処理をすることで断熱材 に蓄積した熱を放熱させ，熱履歴の影響を極力少なくするよ

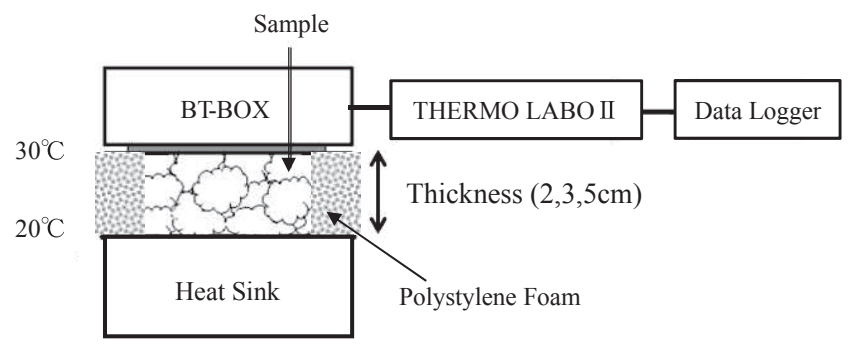

Fig. 3 Measurement of thermal conductivity. 


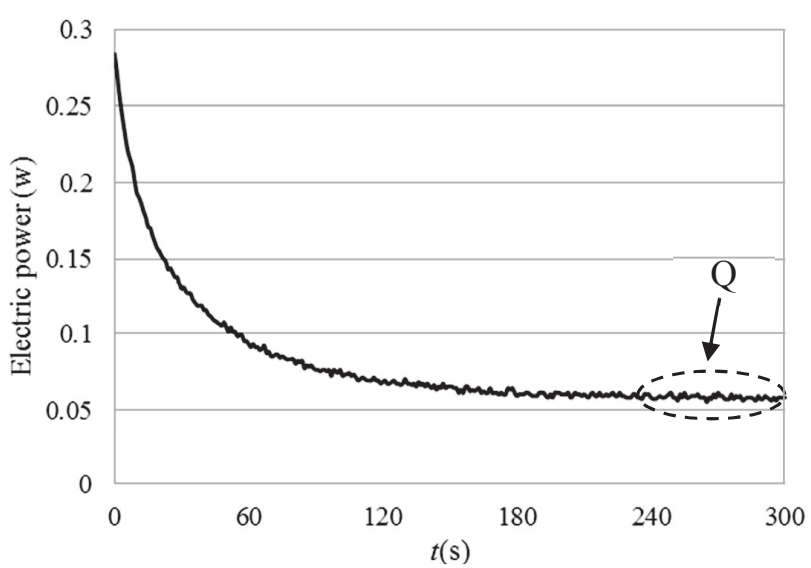

Fig. 4 Method to obtain heat flux in steady state.

\section{う配慮した}

試料を充填した発泡スチロール製断熱枠をヒートシンク上 に置き，BT-Boxの熱板を試料に設置し，定常状態を保つの に必要な電力 $(\mathrm{W})$ を測定する。供給電力の值は, サーモラ ボ Iの所定の出力端子にデータロガーを接続し，1 秒間隔で 経時的に記録した。熱板を試料上に設置してから定常状態に 至るまでのヒーターへの供給電力 $(\mathrm{W})$ 対時間 (s) の関係の 一例を Fig.4 に示す。定常状態を保つのに必要な電力值は, $4 \mathrm{~min}$ から $5 \mathrm{~min}$ の間の時間平均值とした. 有効熱伝導率 $\lambda(\mathrm{W} /$ $\mathrm{mK})$ は次式で求められる。

$$
\lambda=\frac{Q d}{A \Delta T}
$$

ここで, $\mathrm{Q}$ ：定常状態を保つのに必要な電力 $(\mathrm{W}), \mathrm{d}$ ：試 料厚さ $(\mathrm{m}), \mathrm{A}$ ：熱板面積 $\left(\mathrm{m}^{2}\right), \Delta \mathrm{T}$ : 熱板とヒートシンク の温度差 $(\mathrm{K})(=10 \mathrm{~K})$ である。

はじめに，測定者の輻射熱が有効熱伝導率に及ぼす影響を 調べるため, BT-Box およびヒートシンクの前面と左右両側 面の 3 面を縦 $45 \mathrm{~cm} \times$ 横 $45 \mathrm{~cm} \times$ 厚み $3 \mathrm{~cm}$ の発泡スチロール板 （以下，輻射熱ガード板と記す）で覆った場合と覆わない場 合の 2 通りの条件で行った。予備実験の場合, 1 試料 10 回 の繰り返し測定を行い，平均值および標準偏差，変動係数を 求め, 平均值の差の検定を行った。

次に，輻射熱ガード板の有効性を確認した後，BT-Box お よびヒートシンクの前面と左右両側面の 3 面を輻射熱ガード 板で覆い，各種繊維集合体試料の有効熱伝導率を測定する本 実験を行った。

試料枠側面からの熱の漏れが繊維集合体の有効熱伝導率の 測定に及ぼす影響について次のような手続きをとった。一般 に，本測定のような場合の熱の漏れ量の校正のためによく用 いられる方法として, 試料枠内に繊維試料を充填しない状 態 (ブランクと呼ぶ) での有効熱伝導率の測定を行ってみた. 結果は厚さ $3 \mathrm{~cm}$ の場合, $\mathrm{K}=0.07 \mathrm{~W} / \mathrm{mK}$ 程度の值となり，期待 していた空気の熱伝導率值 $(0.026 \mathrm{~W} / \mathrm{mK})$ よりはるかに大き な值となった。その理由としては, 繊維が存在しない条件下 での大きな空気の塊の場合，対流が発生して伝熱量が増大し
たものと推測される。つまり，試料枠内に不動空気が存在す るためには，体積分率 $0.001 \sim 0.03$ 程度の繊維集合体の存在 が必要であると考えられる．以上のように，熱の漏れ量の校 正法としてブランク状態を用いることが不適当であることが 判明したため, 本研究では別のアプローチをとることにした すなわち，本測定では試料の存在下で側面からの熱の漏れを も含めた測定を行い，後述する伝熱の成分分離の考え方を用 いて熱の漏れ量を評価する方法を採用する，参考データとし て, 試料枠を構成する発泡スチロールの有効熱伝導率の測定 を行った。試料寸法は $5 \mathrm{~cm}$ 角, 厚さ $5 \mathrm{~mm}$ の試料 5 枚を用い, 定常法を用いて測定を行った。結果として, 発泡スチロール 板の有効熱伝導率の平均值は $0.035 \mathrm{~W} / \mathrm{mK}$ となり, 後述する 繊維集合体の有効熱伝導率值と近似した值となった。した がって, 試料枠側面からの熱の漏れ量は, 試料である繊維集 合体本体を通る熱流量と同程度となることが予想される。

\section{3. 結 果}

\section{1 測定条件に関する検討}

\subsection{1 ヒートシンクに関する検討}

予備的研究として, 対流熱環境について検討するため, ヒー トシンクに Water Box を使用した場合と冷却ベースを使用し た場合を比較した。 その結果, ヒートシンクとして冷却ベー スを使用した場合のほうがWater Box を使用した場合に比べ て, 平均有効熱伝導率の測定值が有意に大きくなることが認 められた（数值デー夕はとくに示さない）。冷却ベースを使 用した場合の測定部周辺の環境温度の上昇は約 $0.6^{\circ} \mathrm{C}$ である のに対し，Water Box を使用した場合は時間経過とともに環 境温度の上昇が続き，最大で約 $2.1^{\circ} \mathrm{C} の$ 温度上昇がみられた。 このような Water Box を使用した場合の環境温度の上昇は, 恒温循環水槽に付属するモーターおよびファンにより加熱さ れた空気の対流伝熱によるものと考えられる. 環境温度の上 昇により，温められた空気が測定部空間に侵入し，有効熱伝 導率の測定が非常に妨げられていることが確かめられた。以 上より, 纎維集合体の有効熱伝導率の測定には, 対流熱伝達 による測定部周辺の温度上昇をより低く抑えることができる サーモクールをヒートシンクとして使用する方が好ましいと 考えられる。

\section{1 .2 輻射熱ガード板に関する検討}

輻射熱環境の影響について検討する目的で，測定者の輻射 熱が繊維集合体の有効熱伝導率の測定に与える影響に関する 実験を行った。試料, 測定条件および有効熱伝導率の測定結 果をまとめたものを Table 3 に示す。ヒートシンクとして冷 却ベースを使用している。試料 2 種類 (CU, RPE) それぞれに 対し，輻射熱ガード板の有無を組み合わせて計 4 通りの測定 を実施した。各条件につき 10 回の測定を行い, 平均值，標 準偏差および变動係数を求めた。各条件の間の平均值の差の 
Table 3 Results of preparatory experiment for radiation shielding board.

\begin{tabular}{|c|c|c|c|c|c|}
\hline \multirow{2}{*}{ Sample code } & \multirow{2}{*}{ Shielding Board } & \multirow{2}{*}{ Type of Heat Sink } & \multicolumn{2}{|c|}{ Thermal Conductivity (W/mK) } & Coefficient of \\
\cline { 3 - 4 } & & & Average & Standard deviation & variation (\%) \\
\hline CU-A & with & Thermo cool & 0.0514 & 0.0009 & 1.7 \\
\hline CU-B & without & Thermo cool & 0.0533 & 0.0017 & 3.1 \\
\hline RPE-A & with & Thermo cool & 0.0340 & 0.0016 & 4.7 \\
\hline RPE-B & without & Thermo cool & 0.0360 & 0.0012 & 3.4 \\
\hline
\end{tabular}

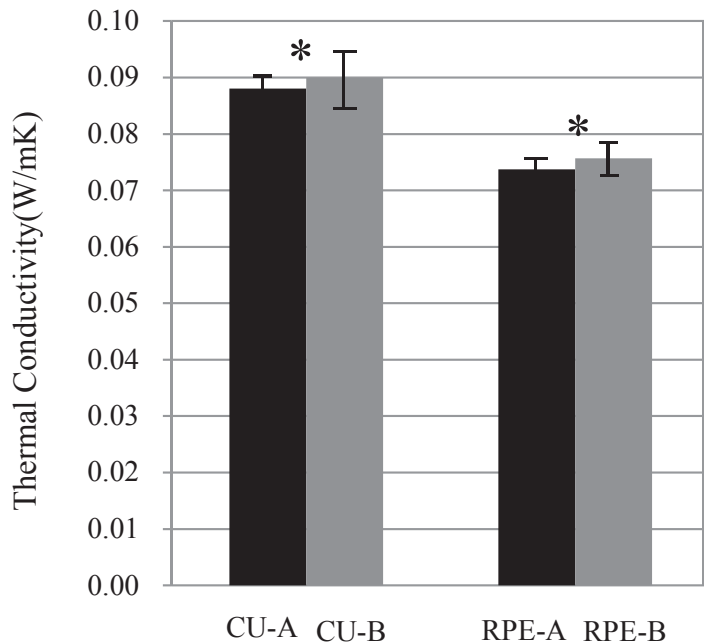

Fig. 5 Comparison of thermal conductivity between "with shielding board" and "without shielding board". (* p <0.01)
d=2cm(CU,RPE,WPE,PTT)

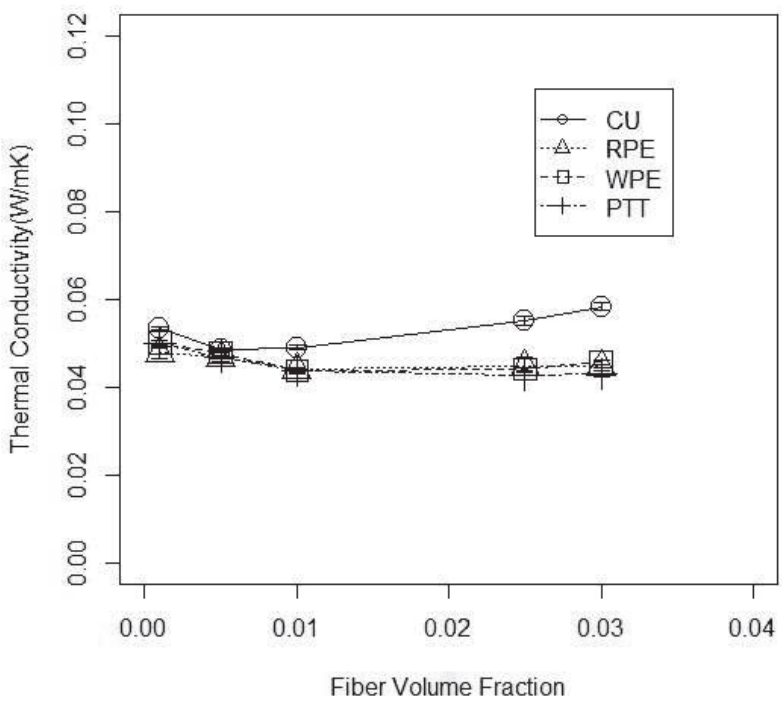

Fig. 6 Thermal conductivity plotted against fiber volume fraction when thickness of sample is $2 \mathrm{~cm}$.
検定を，試料別に $\mathrm{t}$ 検定により行ったＦig.5に，各条件下で の熱伝導率の平均值, 標準偏差を示す。試料 CU および RPE について輻射熱ガード板がある場合は無い場合に比べて，有 効熱伝導率が有意に低い（危険率 1\%)，その理由として，輻 射熱ガード板が無い場合は, 人体（測定者）からの輻射伝熱 がもう一つの熱源となって式 (2) の熱流束 Q を大きくしてお り，その結果ガード板がある場合に比べて，有効熱伝導率の 值を大きくしているものと推測される。したがって, 繊維集 合体の有効熱伝導率の測定に際しては，輻射熱ガード板を測 定部周囲に設置した方が，測定者からの輻射伝熱を遮蔽する ため, より正確な熱伝導率值を求めることができるといえる. また，輻射熱ガード板がある場合は無い場合に比べて，標準 偏差と変動係数が小さくなる傾向がある，以上より，低体積 分率の繊維集合体の有効熱伝導率を, より正確, 精密に測定 するためには，測定部周辺に輻射熱ガード板を設置して行う 必要があることが示された

\section{2 短繊維集合体の有効熱伝導率}

上述の測定条件および実験方法にしたがって，試料の厚み を 3 条件, 繊維体積分率を 5 条件に変えて, 短繊維集合体の 有効熱伝導率の測定を行った。 測定により求めた有効熱伝導
率の結果について, 繊維体積分率, 試料の厚さ, 繊維素材等 との関係を検討する。本実験では，各条件につき 3 回の測定 をおこない, 平均值, 標準偏差を求めた。

はじめに纎維体積分率と有効熱伝導率の関係について, 繊 維素材と関連させて述べる. Figs.6〜8に各試料における体 積分率と有効熱伝導率の関係を示す. Fig.6 は試料の厚さが $2 \mathrm{~cm}$ の場合, Fig. 7 は試料の厚さが $3 \mathrm{~cm}$ の場合, Fig. 8 は試料 の厚さが $5 \mathrm{~cm}$ の場合の結果である。いずれも縦軸は有効熱伝 導率 $(\mathrm{W} / \mathrm{mK})$, 横軸は繊維体積分率 (n.d.) である。有効熱伝 導率の大きさのレベルは, 同一試料について試料厚さが $2 \mathrm{~cm}$, $3 \mathrm{~cm}, 5 \mathrm{~cm}$ と増加するにつれて増加している。このような厚 さによる変化については後述するとして，ここでは，有効熱 伝導率対繊維体積分率の関係に及ぼす繊維素材の影響につい て，主として試料厚さ $5 \mathrm{~cm}$ における結果 (Fig.8) に関して検 討する. 試料厚さが一定の場合, 各素材の有効熱伝導率の大 きさを比較すると, 同じ体積分率では CU が最も大きく, 次 にポリエステル繊維のグループ (RPE, WPE, PTT) の順であ る。 RPE,WPE およびPTTの間では本測定法の範囲内で有意 な差は認められない.

次に, 有効熱伝導率対繊維体積分率の関係に及ぼす繊維素 材の影響について検討する。いずれの試料においても，有効 熱伝導率対繊維体積分率の関係は下に凸な曲線を示す。繊維 
$d=3 \mathrm{~cm}(\mathrm{CU}, \mathrm{RPE}$, WPE,PTT $)$

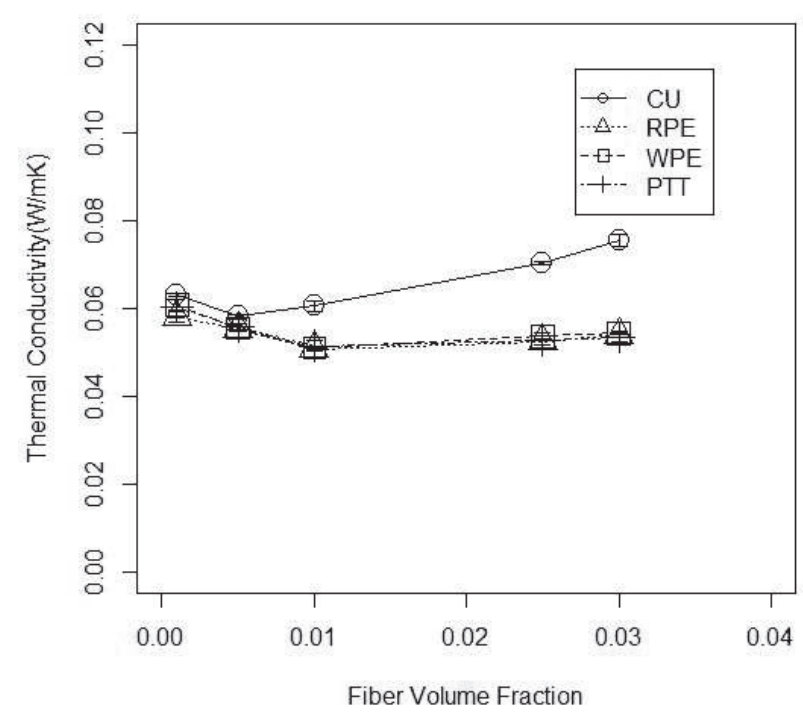

Fig. 7 Thermal conductivity plotted against fiber volume fraction when thickness of sample is $3 \mathrm{~cm}$.
Fiber Volume Fraction:0.01(CU,RPE,WPE,PTT)

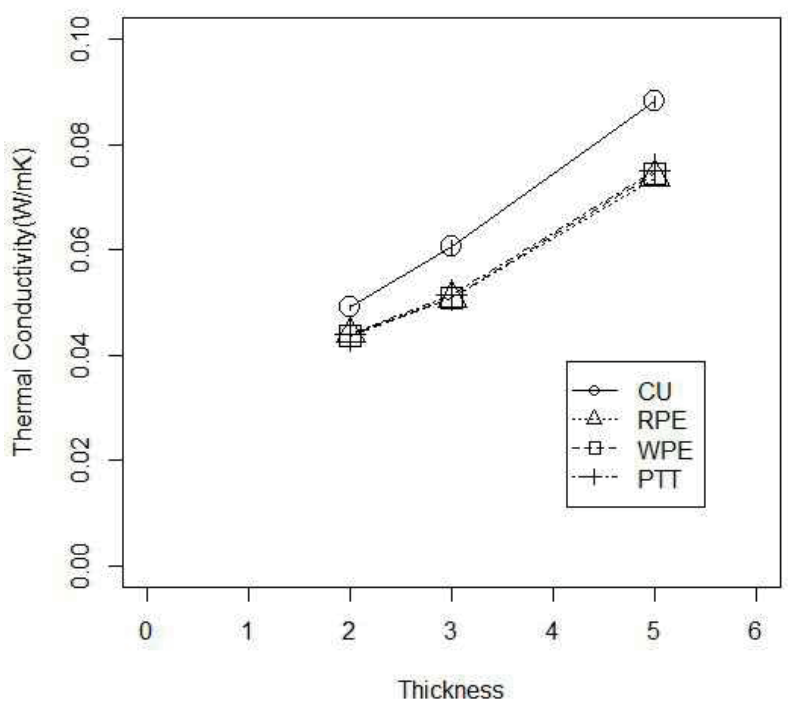

Fig. 9 Thermal conductivity plotted against thickness when volume fraction of sample is 0.01 .
素材による曲線形状の特徵は以下の通りである. CUは熱伝 導率の極小值が体積分率 0.005 付近にあり, 体積分率の増加 とともに増加の傾向にある。 RPE,WPE およびPTTについて は熱伝導率の極小值は体積分率 0.01 付近にあり, 体積分率 0.03 に向けてやや増加している。 また, CU は繊維体積分率 が 0.005 から 0.001 にかけて減少するとき, RPE, WPE, PTT は繊維体積分率が 0.01 から 0.001 にかけて減少するとき, 熱 伝導率はわずかに増加している。 さらに, 試料の厚さが $3 \mathrm{~cm}$, $2 \mathrm{~cm}$ と減少することにより, 熱伝導率值のレベルが低下する とともに, 曲線形状が平坦化して繊維素材の特徵が薄れ, 繊 維素材間の差が小さくなる傾向にある.

\section{$\mathrm{d}=5 \mathrm{~cm}$ (CU,RPE,WPE,PTT)}

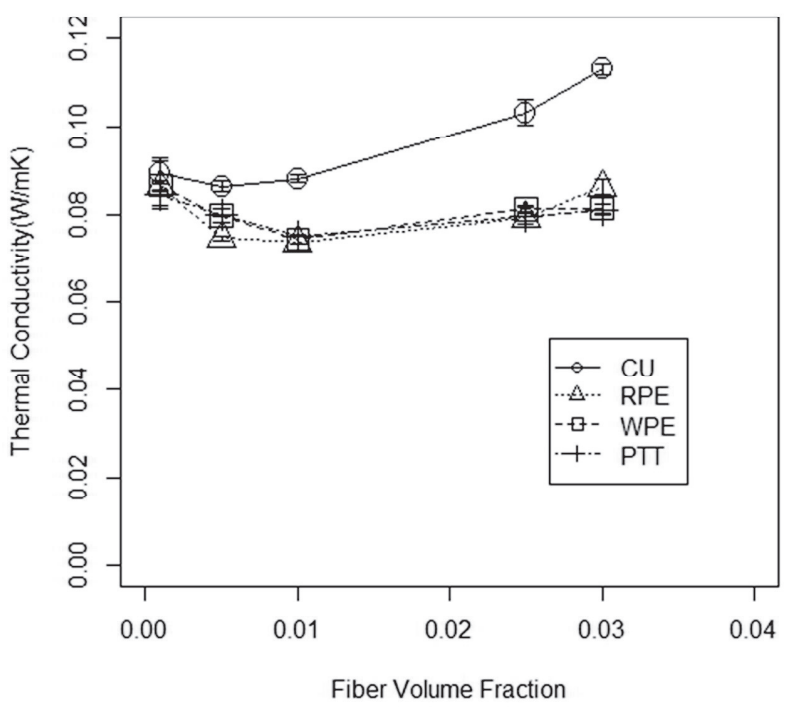

Fig. 8 Thermal conductivity plotted against fiber volume fraction when thickness of sample is $5 \mathrm{~cm}$.
次に試料の厚さと熱伝導率の関係について検討する。一例 として Fig.9 に体積分率 0.01 における試料の厚さと有効熱伝 導率の関係を示す。縦軸は熱伝導率 $(\mathrm{W} / \mathrm{mK})$, 横軸は試料の 厚さ $(\mathrm{cm})$ である. Fig.9よりいずれの試料についても, 試料 の厚さに対して熱伝導率は直線的に増加していることがわか る. 直線の傾きから判断すると, CUは他の合成繊維（RPE, WPE， PTT）に比べて増加の割合がやや大きい傾向がみられ る. 次節以下において, 本測定で得られた有効熱伝導率の各 要素過程への成分分離について検討する. 有効熱伝導率の厚 さ依存性については, 成分分離に関する検討を行った後で, 改めて考察する.

\section{4. 非線形回帰モデルによる解析}

本研究で取り扱っている繊維集合体の空隙率は非常に大き いため, 集合体内部での熱移動の形態には空隙に関わる効果 が強く現れているものと考えられる.すなわち, 纎維中の熱 伝導, 繊維間空隙内での輻射伝熱, および, 空隙中の気体（空 気）を介した熱伝導である。これら 3 つ伝熱要素が熱流に 対して並列に配置されていると仮定する（並列モデル）と， 有効熱伝導率の測定值 $\lambda$ は嵩密度 $\rho$ (bulk density, $\left.\mathrm{kg} / \mathrm{m}^{3}\right)$ の関 数として，3つの要素の和で表される $[5-8]$.

$$
\lambda=\mathrm{A} \rho+\mathrm{B} / \rho+\mathrm{C}
$$

ここで, $\mathrm{A}\left(\mathrm{Wm}^{2} / \mathrm{Kkg}\right), \mathrm{B}\left(\mathrm{Wkg} / \mathrm{m}^{4} \mathrm{~K}\right)$ は係数, $\mathrm{C}(\mathrm{W} / \mathrm{mK})$ は 定数である. 右辺第 1 項は繊維中の伝導伝熱項, 第 2 項は繊 維間空隙内の輻射伝熱項, 第 3 項は空隙中の気体を介した伝 導伝熱項を表している。（パラメータ A,B,Cの詳細について は付録に示す.）

各種繊維集合体における有効熱伝導率の測定結果につい て,式（3）を適用して解析を行い，A，B，Cを決定した，ただし， 


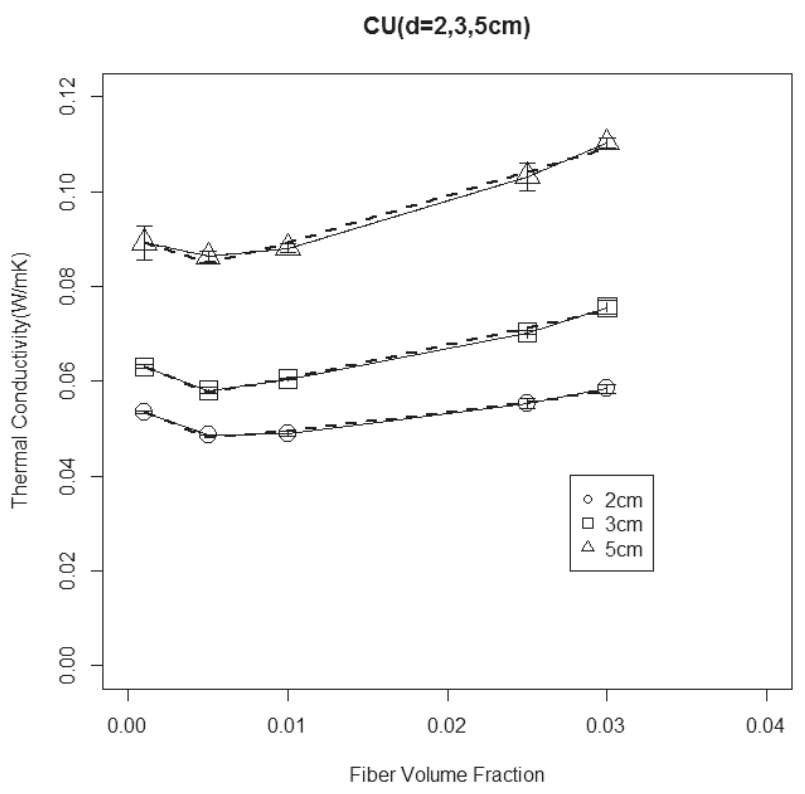

Fig. 10 Comparison between calculated and measured values for $\mathrm{CU}$.

Symbol $\circ, \square, \Delta$ and Straight line: measured values Broken line: calculated values obtained by nonlinear regression analysis

$\operatorname{RPE}(\mathrm{d}=2,3,5 \mathrm{~cm})$

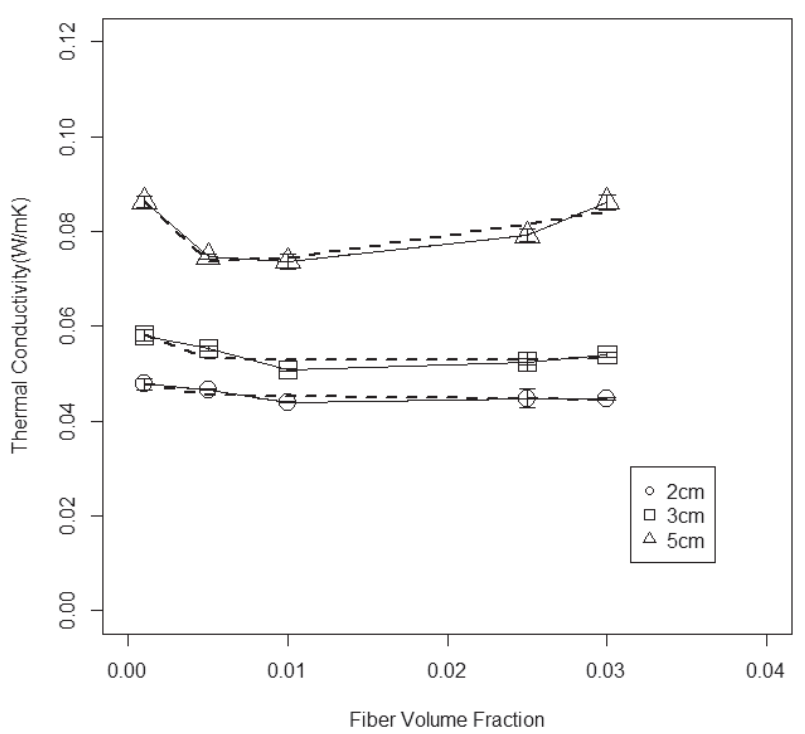

Fig. 11 Comparison between calculated and measured values for RPE.

Symbol $\circ, \square, \Delta$ and Straight line: measured values Broken line: calculated values obtained by nonlinear regression analysis

本研究においては以下のように嵩密度 $\rho$ を繊維体積分率 $\varphi$ に 読み換えて解析を行っている。これは，回帰式における $\varphi$ の 役割が $\rho$ と同等であるためである。

$$
\lambda=\mathrm{A} \varphi+\mathrm{B} / \varphi+\mathrm{C}
$$

WPE $(\mathrm{d}=2,3,5 \mathrm{~cm})$

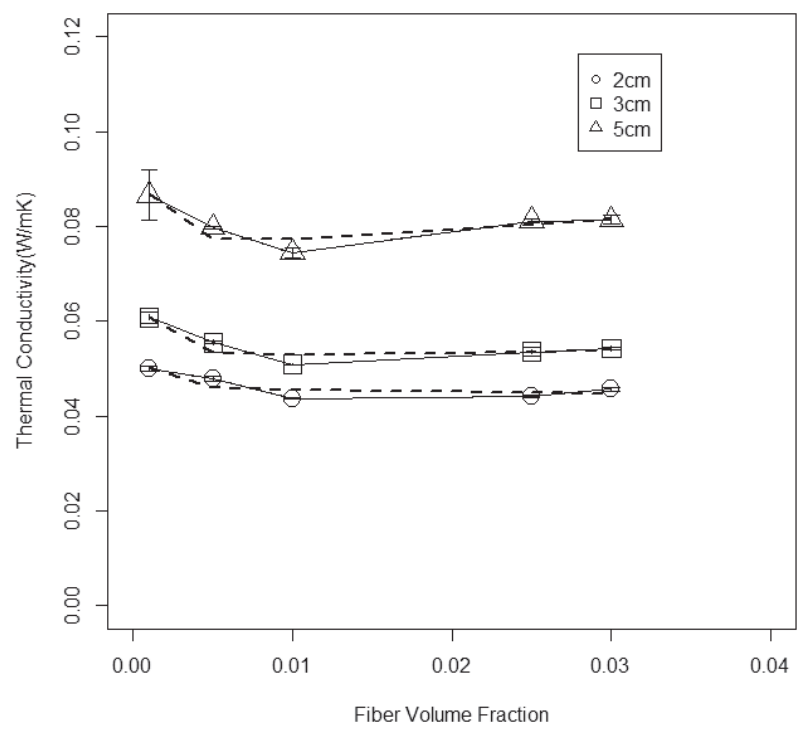

Fig. 12 Comparison between calculated and measured values for WPE.

Symbol $\circ, \square, \Delta$ and Straight line: measured values Broken line: calculated values obtained by nonlinear regression analysis

$\operatorname{PTT}(\mathrm{d}=2,3,5 \mathrm{~cm})$

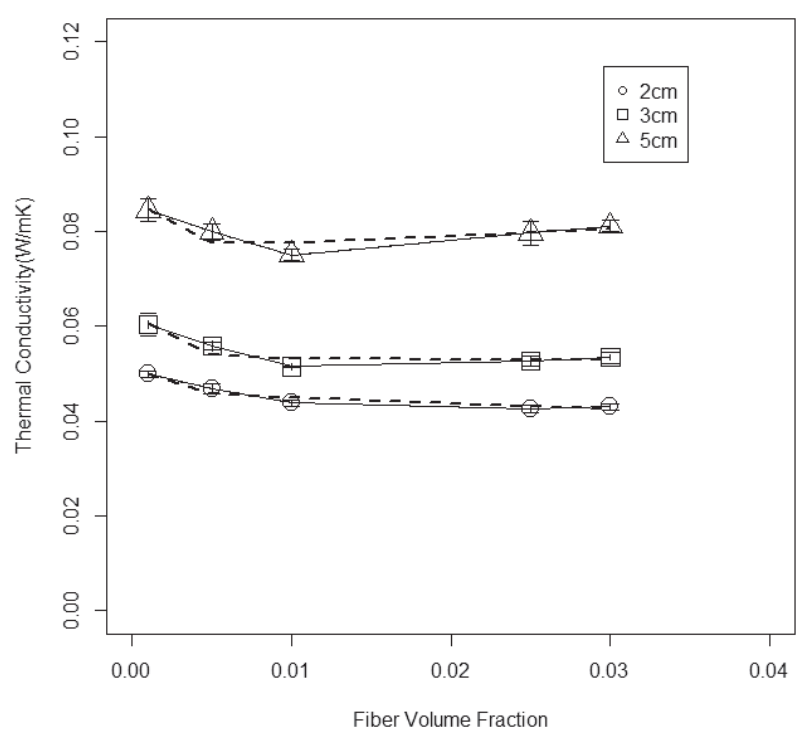

Fig. 13 Comparison between calculated and measured values for PTT.

Symbol $\circ, \square, \Delta$ and Straight line: measured values Broken line: calculated values obtained by nonlinear regression analysis

非線形回帰分析は $\mathrm{R}$ 言語（Ver.3.1.1）を用いて行った。非 線形回帰分析による各パラメー夕の推定值を Table 4 に，お よび，推定值に基づく計算結果を Figs.10〜 12 に示す。 それ ぞれ $\mathrm{A}$ は繊維伝導成分の係数, $\mathrm{B}$ は輻射成分の係数, $\mathrm{C}$ は ガス伝導成分（定数）である. Fig.10は CU, Fig.11 は RPE, 
$d=3 \mathrm{~cm}(C U)$

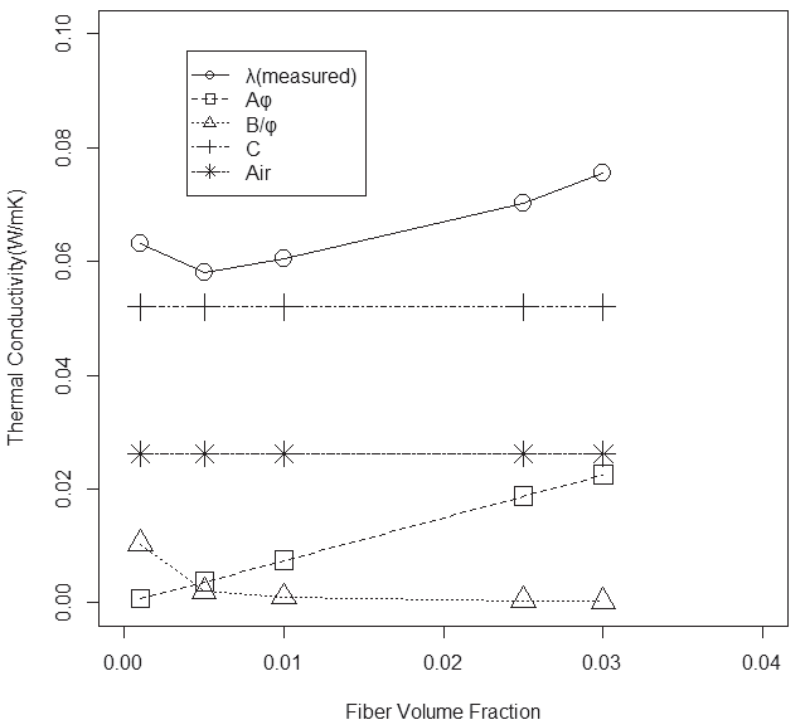

Fig. 14 Separation of heat transfer component by nonlinear regression analysis for $\mathrm{CU} .(\mathrm{d}=3 \mathrm{~cm})$

$\mathrm{d}=3 \mathrm{~cm}(\mathrm{RPE})$

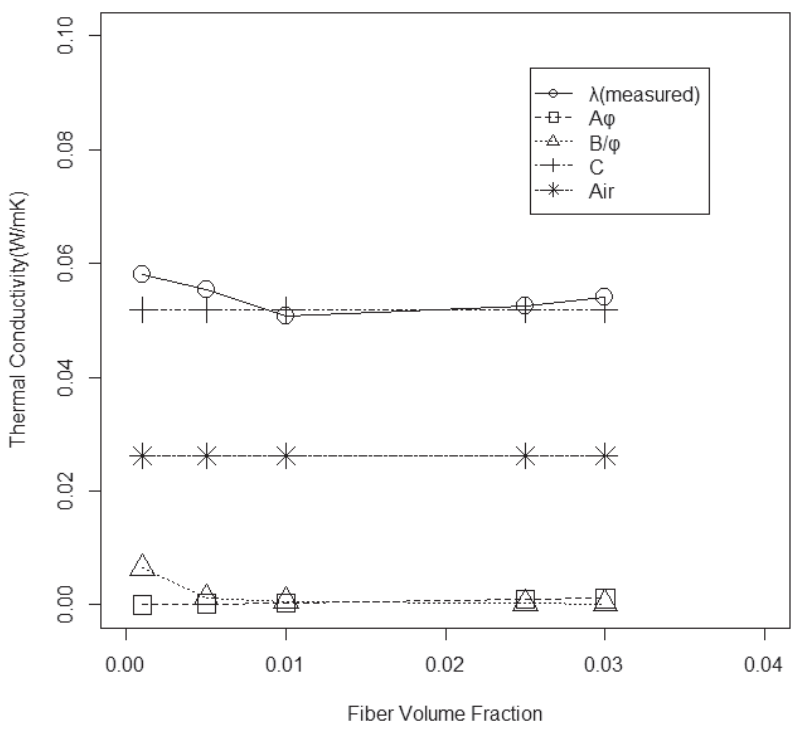

Fig. 15 Separation of heat transfer component by nonlinear regression analysis for RPE. $(\mathrm{d}=3 \mathrm{~cm})$

Fig.12 はWPE, Fig.13はPTTについて, それぞれ試料の厚 さ $\mathrm{d}$ が $2 \mathrm{~cm}, 3 \mathrm{~cm}, 5 \mathrm{~cm}$ の場合の結果を示している。縦軸は 有効熱伝導率 $\lambda$, 横軸は繊維体積分率である。ここで記号 $(\bigcirc$, $\square ， \triangle ）$ およ゙実線は実測值，破線は実測值を用いて得られ た近似曲線である。図に示したように、いずれの䋊維集合体 においても有効熱伝導率の実測值と非線形回帰分析による計 算結果の一致は良好であると考えられる。

次に，非線形回帰分析により分離した成分の係数 A, B お よび定数 Cの值を用いて, 各項別に計算した結果について検 $\mathrm{d}=3 \mathrm{~cm}$ (WPE)

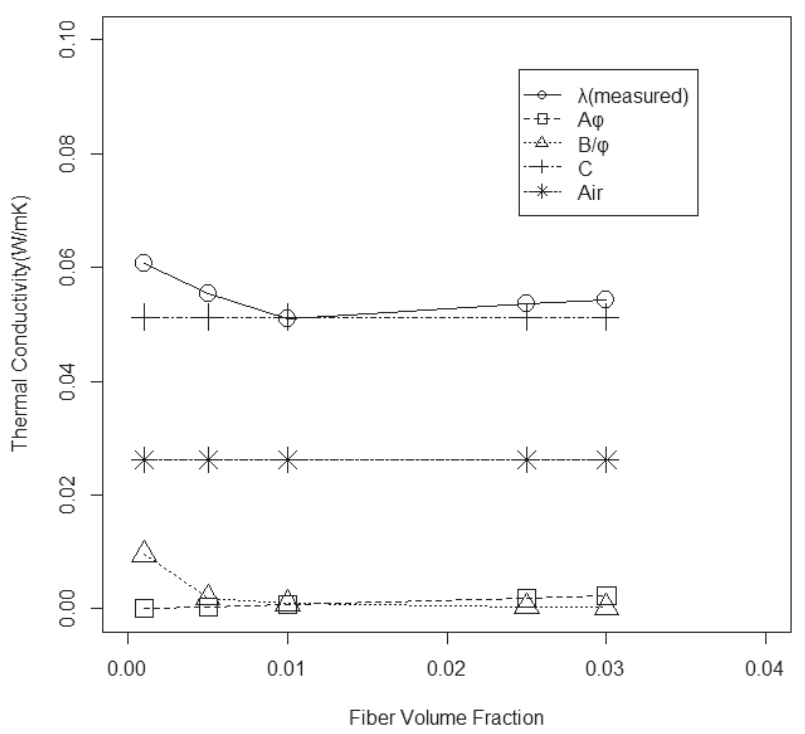

Fig. 16 Separation of heat transfer component by nonlinear regression analysis for WPE. $(\mathrm{d}=3 \mathrm{~cm})$

$d=3 \mathrm{~cm}(\mathrm{PTT})$

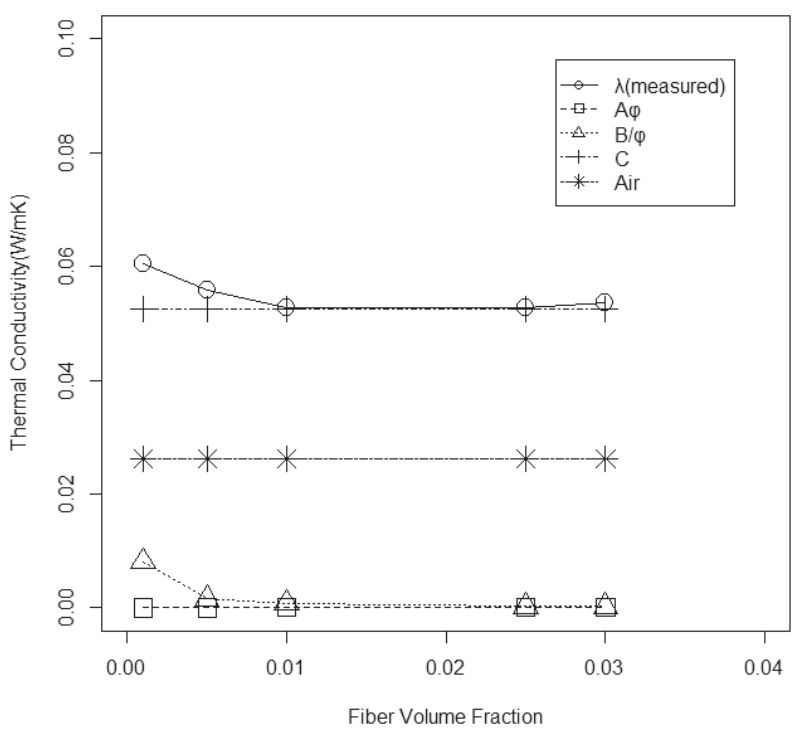

Fig. 17 Separation of heat transfer component by nonlinear regression analysis for PTT. $(\mathrm{d}=3 \mathrm{~cm})$

討する. 各繊維素材の解析結果の一例を Figs. $14 〜 17$ に示す. Fig.14 は CU, Fig.15 は RPE, Fig.16 は WPE, Fig.17は PTT について, 試料厚さ $\mathrm{d} か ゙ 3 \mathrm{~cm}$ の場合の結果を示している。縦 軸は有効熱伝導率 $\lambda(\mathrm{W} / \mathrm{mK})$, 横軸は繊維体積分率 (n.d.) で ある。破線が繊維伝導成分 $\mathrm{A} \varphi$, 一点鎖線が輻射成分 $\mathrm{B} / \varphi, 2$ 点鎖線がガス伝導成分 $\mathrm{C}$ であり，実線は有効熱伝導率の実測 值を示す。このグラフを利用することにより, 各䋊維素材に おける各要素成分の割合, および, これらに対する繊維集合 体の空隙の効果について検討することができる。また，繊維 
素材および繊維の断面形状によって, 繊維伝導成分 $\mathrm{A} \varphi$ と輻 射成分 $\mathrm{B} / \varphi$ およびガス伝導成分 $\mathrm{C}$ の割合が異なることがわか る.

はじめに，繊維伝導成分 $\mathrm{A} \varphi$ について検討する。係数 $\mathrm{A}$ は 繊維素材によって大きく異なっていることがわかる。キュプ ラ $(\mathrm{CU})$ はポリエステル系繊維素材 (RPE,WPE, PTT) に比べ て大きな係数 $\mathrm{A}$ を持っており, 繊維体積分率 $\varphi$ に対する増 加率が大きい. 結果として, $\varphi=0.03$ において有効熱伝導率の うち 3 割以上を占めるに至っている。一方, ポリエステル系 素材の場合, もっとも A が大きいWPEでも $\varphi=0.03$ において 2 割以下と小さい. 以上のように，本測定の範囲内において CU は纎維伝導成分の占める割合, および, 繊維体積分率に 対する増加の割合がポリエステル系素材に比べて大きいこと が特徵的である。

次に, 輻射伝熱成分 $B / \varphi$ について検討する，本測定の範囲

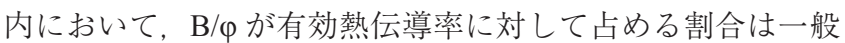
に無視できるほど小さい. $B / \varphi$ の寄与は $\varphi=0.005$ 以下におい てわずかに認められる。 $\varphi=0.005$ から 0.001 にかけて, いず れの試料においても空隙率の増加に対して輻射伝熱成分の増 加が認められる。本研究における輻射伝熱成分の割合は, 野 飼, 藤本 [1-3]らの結果に比べて著しく小さい.これは, 野飼, 藤本らが配向度の高い繊維集合体を研究対象としているのに 対し, 本研究ではランダム配向繊維集合体を取り扱っている ためであると考えられる。すなわち, ランダム配向繊維集合 体においては輻射の平均自由行程は一般に小さくなるためで ある。（例えば，一軸配向繊維集合体においては，輻射熱流 束が熱源板とヒートシンクを直通することが起こり得る.)

最後に，ガス伝導成分 Cについて検討する。 Figs.14-17 を みると CUにおける繊維体積分率 $\varphi$ の全範囲，および，ポリ エステル系繊維素材の $\varphi<0.005$ の部分を例外として, 多くの 場合, 繊維集合体の有効熱伝導率の大部分をガス伝導成分 $\mathrm{C}$ が占めていることがわかる。そこで，本測定により求めたガ 又伝導成分 $\mathrm{C}$ の物理的内容について検討を行う. Table4 下段 に厚さ $2,3,5 \mathrm{~cm}$ における各試料の C の推定值を示す．表より $\mathrm{C}$ 值は各厚さにおいて試料の違いにかかわらず，ほぼ一定值

Table 4 List of coefficients A, B and constant C.

\begin{tabular}{|c|c|c|c|c|}
\hline \multirow{2}{*}{ Parameter } & \multirow{2}{*}{ Sample code } & \multicolumn{3}{|c|}{ Thickness of a sample } \\
\hline & & $2 \mathrm{~cm}$ & $3 \mathrm{~cm}$ & $5 \mathrm{~cm}$ \\
\hline \multirow{4}{*}{ A } & $\mathrm{CU}$ & $4.51 \times 10^{-1}$ & $7.51 \times 10^{-1}$ & 1.04 \\
\hline & RPE & $-2.45 \times 10^{-2}$ & $3.76 \times 10^{-1}$ & $5.54 \times 10^{-1}$ \\
\hline & WPE & $-1.68 \times 10^{-2}$ & $7.68 \times 10^{-2}$ & $2.51 \times 10^{-1}$ \\
\hline & PTT & $-1.04 \times 10^{-1}$ & $5.25 \times 10^{-3}$ & $1.83 \times 10^{-1}$ \\
\hline \multirow{4}{*}{ B } & $\mathrm{CU}$ & $9.03 \times 10^{-6}$ & $1.04 \times 10^{-5}$ & $1.05 \times 10^{-5}$ \\
\hline & RPE & $2.73 \times 10^{-6}$ & $6.42 \times 10^{-6}$ & $1.89 \times 10^{-5}$ \\
\hline & WPE & $5.20 \times 10^{-6}$ & $9.62 \times 10^{-6}$ & $1.30 \times 10^{-5}$ \\
\hline & PTT & $4.68 \times 10^{-6}$ & $8.10 \times 10^{-6}$ & $9.75 \times 10^{-6}$ \\
\hline \multirow{4}{*}{$\mathrm{C}$} & $\mathrm{CU}$ & $4.41 \times 10^{-2}$ & $5.20 \times 10^{-2}$ & $7.78 \times 10^{-2}$ \\
\hline & RPE & $4.52 \times 10^{-2}$ & $5.18 \times 10^{-2}$ & $6.70 \times 10^{-2}$ \\
\hline & WPE & $4.51 \times 10^{-2}$ & $5.13 \times 10^{-2}$ & $7.36 \times 10^{-2}$ \\
\hline & PTT & $4.54 \times 10^{-2}$ & $5.25 \times 10^{-2}$ & $7.48 \times 10^{-2}$ \\
\hline \multicolumn{2}{|r|}{ Alr } & $2.62 \times 10^{-2}$ & $2.62 \times 10^{-2}$ & $2.62 \times 10^{-2}$ \\
\hline
\end{tabular}

Table 5 Figures for the calibration of leakage of heat.

\begin{tabular}{|c|c|c|c|}
\hline Thickness $(\mathrm{cm})$ & $\mathrm{C}_{\text {mean }}$ & $\lambda_{\text {air }}$ & $\mathrm{C}^{\prime}$ \\
\hline 2 & $4.495 \times 10^{-2}$ & $2.62 \times 10^{-2}$ & $1.875 \times 10^{-2}$ \\
\hline 3 & $5.19 \times 10^{-2}$ & $2.62 \times 10^{-2}$ & $2.57 \times 10^{-2}$ \\
\hline 5 & $7.33 \times 10^{-2}$ & $2.62 \times 10^{-2}$ & $4.71 \times 10^{-2}$ \\
\hline
\end{tabular}

をとっているように見える。一方，Table4 最下段に，本測定 条件 $\left(25^{\circ} \mathrm{C}, 1 \mathrm{~atm}\right)$ に打ける空気の有効熱伝導率 $\lambda_{\text {air }}$ の文献值 $2.62 \times 10^{-4}(\mathrm{~W} / \mathrm{mK})$ を示す [9]. ここで, C 值が試料にかかわ らずある厚さで一定值を持つという事実，および， C 值の中 に空気の有効熱伝導率が含まれていることを考慮して， C 值 を次の形に表す.

$\mathrm{C}=\lambda_{\text {air }}+\mathrm{C}^{\prime}$

ここで，C'は纎維体積分率 $\varphi$ に依存しない定数とする. Table5 に本考察に関わるパラメータとして，各厚さにおける $\mathrm{C}$ の平均值, $\lambda_{\text {air }}, \mathrm{C}^{\prime}$ の值を示す。原点を含めて C' 対厚さ の関係に線形回帰を適用する。結果を Fig.18 に示す。回帰式 は次のように与えられる。

$$
C^{\prime}=0.9325 d-0.0425 \quad\left(R^{2}=0.996\right)
$$

切片は 0 に近い值であることより, C' は非常によい精度 で厚さ $\mathrm{d}$ に関する同次の一次式 $\left(\mathrm{C}^{\prime}=\mathrm{kd}: \mathrm{k}\right.$ は定数) で表せる ことがわかる

ここで，C’がスチロール枠側面からの熱のもれ成分と見 なせるかどうかについて考察する。試料充填部の断面が $5 \mathrm{~cm}$ 平方であることを考慮すると, スチロール枠の側面積 A は A $=4 \times 5 \times$ d $\left(\mathrm{cm}^{2}\right)$ と表せる. 枠の表面には熱源からヒートシ ンクにかけて厚さ方向に温度勾配が存在するが, 簡単化のた めにこれを無視して, 水平方向に単位面積あたり熱のもれる 量を一定值と仮定すると，側面からの熱のもれ Q' は側面の 面積に比例する。すなわち $\mathrm{Q}^{\prime} \propto \mathrm{A} \propto \mathrm{d}$. 以上より，側面か

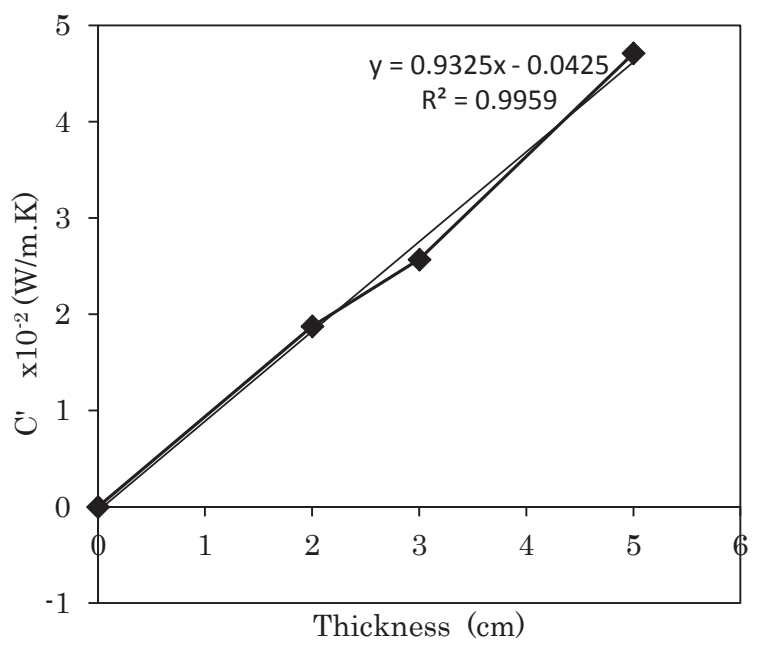

Fig. 18 Function for the calibration of leakage of heat. 
$\mathrm{d}=3 \mathrm{~cm}(\mathrm{CU})$

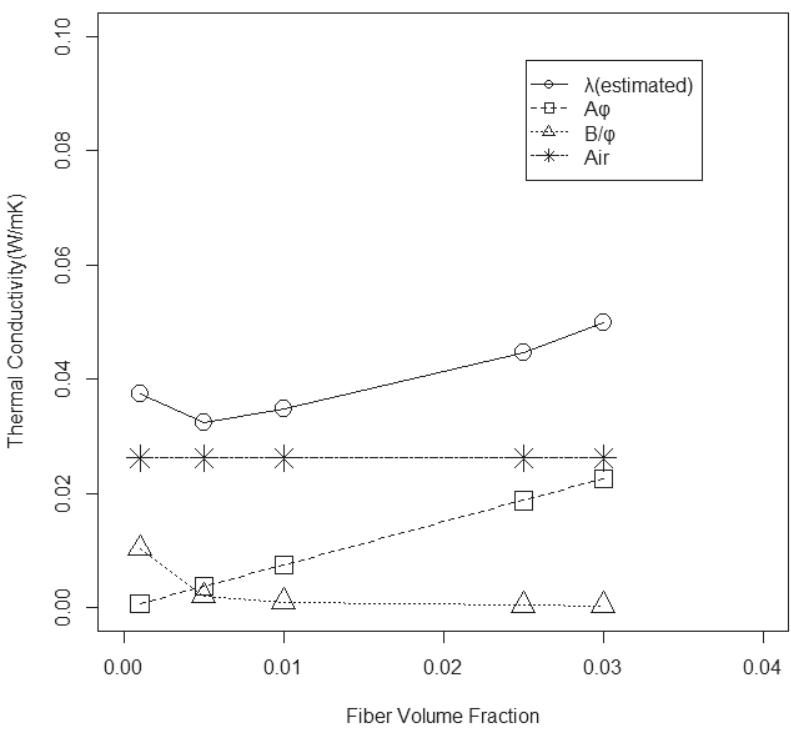

Fig. 19 Estimated values of effective thermal conductivity and its component. (Sample: $\mathrm{CU}, \mathrm{d}=3 \mathrm{~cm}$ )

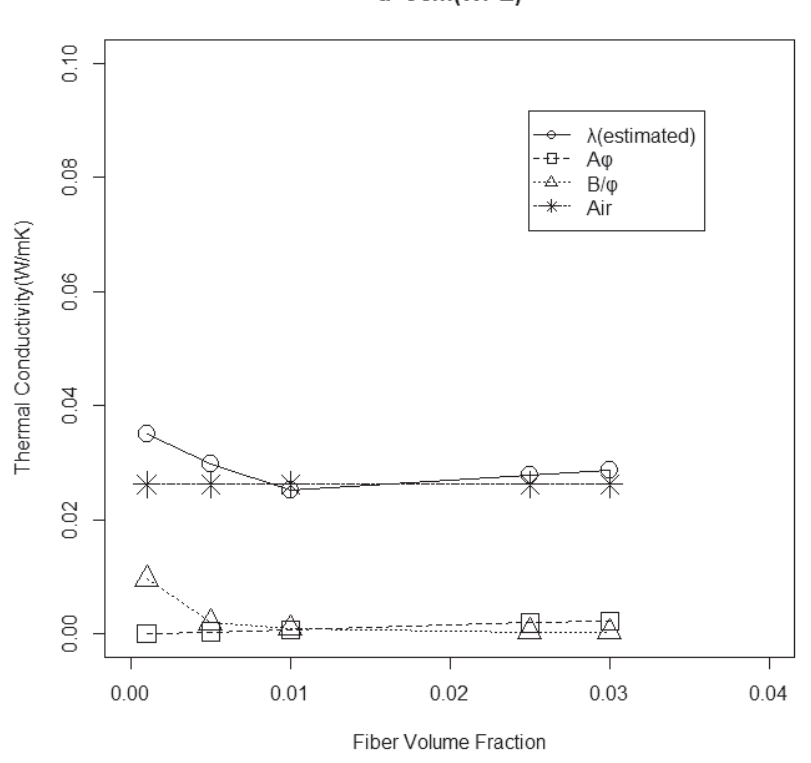

Fig. 21 Estimated values of effective thermal conductivity and its component. (Sample: WPE, $\mathrm{d}=3 \mathrm{~cm}$ )
らの熱のもれは厚さ $\mathrm{d}$ に比例し，厚さが 0 のとき 0 という性 質をもつ. C’も同じ性質をもつことから，C'はスチロー ル枠側面からの熱のもれと見なしてよいものと考えられる.

以上の考察に基づき, $\mathrm{C}$ 值から C' 值を取り除き改めて $\mathrm{C}=\lambda_{\text {air }}$ と見なして Figs.14-17を書き改めたものを Figs.19-22 に示す。図より，低纎維体積分率における有効熱伝導率の大 部分が，ごくわずかな量の繊維 $(\varphi<0.03)$ によってトラップ された静止空気の熱伝導率であることが推測される。一方， 繊維素材の違いによる熱伝導性の差異は䋊維伝導成分の係数 Aにあらわれている，本測定における繊維体積分率の範囲に おいて，キュプラの $\mathrm{A} \varphi$ 成分が比較的大きいのに対し，ポリ

$\mathrm{d}=3 \mathrm{~cm}(\mathrm{RPE})$

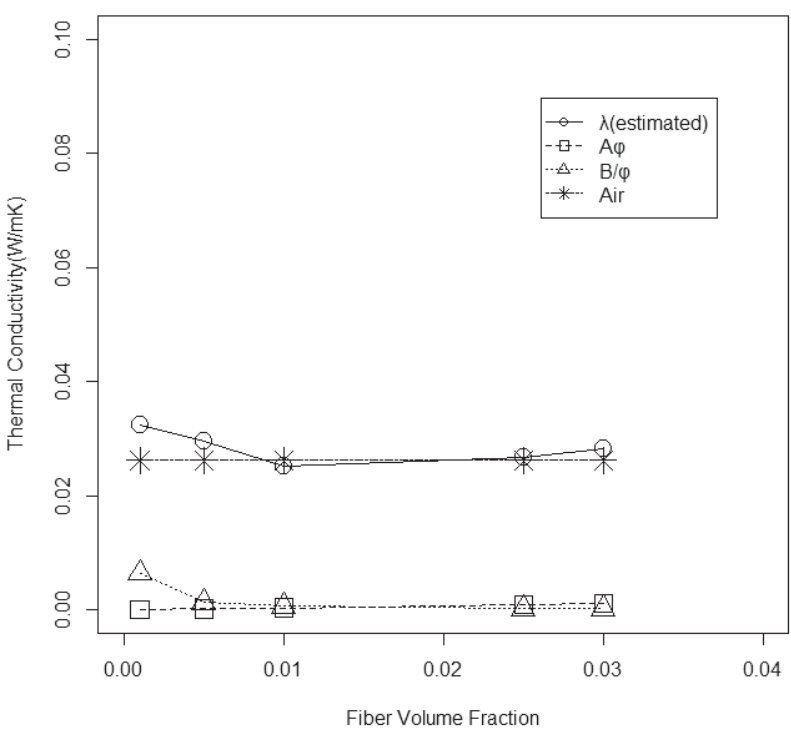

Fig. 20 Estimated values of effective thermal conductivity and its component. (Sample: RPE, $d=3 \mathrm{~cm}$ )
エステル系繊維素材の $\mathrm{A} \varphi$ 成分が小さいことがわかる。この うち，保温性素材として有利なのは広い体積分率の範囲にわ たって小さな $\mathrm{A} \varphi$ 成分をもつポリエステル系素材であるとい える

以上，非線形回帰モデルにより，短繊維集合体の有効熱伝 導率の測定值を繊維伝導成分，輻射成分，ガス伝導成分，お よび，熱の漏れ成分に分離することができた。このうち，繊 維集合体における保温性の実現には, 繊維集合構造による不 動空気の形成が最も重要な要因であることが示された。次い で，繊維伝導成分がとくに繊維体積分率の大きい部分で 2 番 目に多い成分となっていることがわかった，各成分の占める

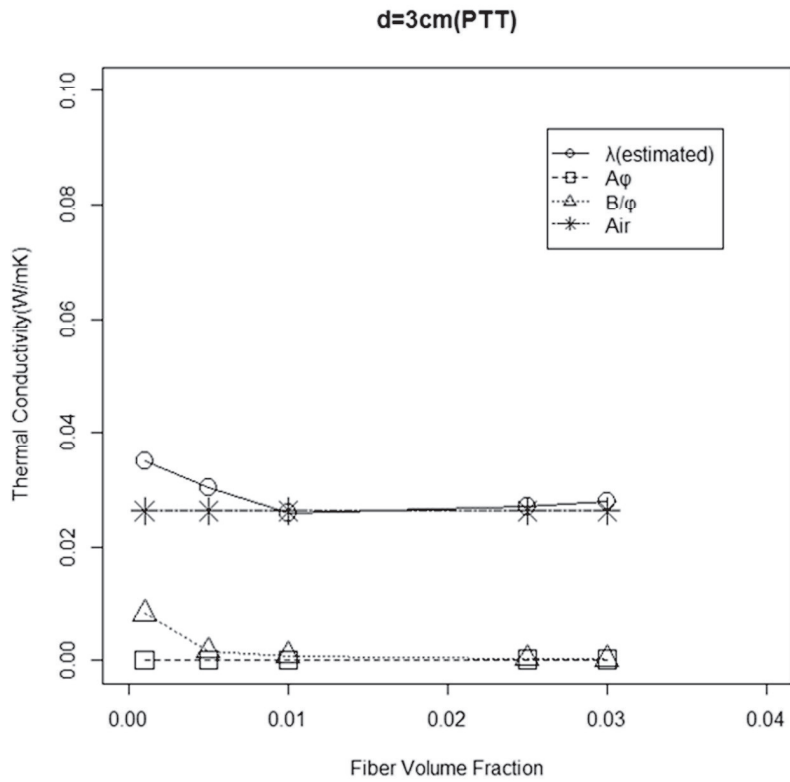

Fig. 22 Estimated values of effective thermal conductivity and its component. (Sample: PTT, $d=3 \mathrm{~cm}$ ) 
割合は，主として繊維素材の違い，および，それに伴う空隙 の効果が関係していることが推測される，輻射成分は, 繊維 体積分率の小さい部分で，わずかに認められた．以上の知見 は, 保温性の実現を目的とした低い体積分率の繊維集合体の 材料設計にあたって基礎的な情報となる。

\section{5. 結 言}

本研究では, 寝装用中わた部材を構成する繊維として現在 流通している試料の中から, キュプラ $(\mathrm{CU})$, 丸断面ポリエ ステル (RPE), 異型断面ポリエステル (WPE), ポリトリメ チレンテレフタレート (PTT) からなる 4 種の短纎維集合体 を採り上げ，それぞれの有効熱伝導率を測定した。本測定で 用いる試料特有の性質を考慮して, 熱源以外からの測定装置 一試料系への熱の流入を極力排除し，あわせて，試料枠から の熱の漏れ量の校正を考慮に入れた有効熱伝導率の測定を行 うよう注意を払った

有効熱伝導率の測定は, 繊維体積分率の水準をいくつか変 化させて行い, 有効熱伝導率曲線を求めた。 有効熱伝導率曲 線の解析には伝熱成分の成分分離を考慮に入れた実験式を採 用し，非線形回帰分析により解析を行った。試料枠側面から の熱の漏れは，これを含めた形で測定を行い，成分分離と同 時に熱の漏れ量の校正を行う。またヒートシンクとして冷却 ベース（ペルチェ素子を用いて冷却する）を採用し，測定部 周囲に輻射熱ガード板を設置することにより，測定系への熱 の流入を排除するよう配慮した。得られた結果は以下の通り である。

（1）有効熱伝導率対繊維体積分率 $\varphi$ の関係は, いずれの 試料においても下に凸な曲線，または平坦な形状を示す. $\mathrm{CU}$ では有効熱伝導率の極小值が $\varphi=0.005$ 付近にあり, RPE,WPE, PTT では有効熱伝導率の極小值は $\varphi=0.01$ 付近 にある

（2）非線形回帰分析により, 繊維集合体の有効熱伝導率は 伝導成分 $A \varphi$, 輻射成分 $\mathrm{B} / \varphi$ およびガス伝導成分 $\mathrm{C}$ に分離で きる。

（3）ガス伝導成分 $\mathrm{C}$ は, 空気の熱伝導率 $\lambda$ air と試料枠側 面からの熱の漏れ C'に分離できる.

（4）有効熱伝導率に対する寄与はガス伝導成分 C が最も大 きい。,ついで, 繊維体積分率の大きい範囲で, 繊維伝導成分 $\mathrm{A} \phi$ の寄与が大きい. 輻射成分 $\mathrm{B} / \varphi$ の寄与は全体的に小さい.

(5) 各素材の有効熱伝導率の大きさを比較すると, 同じ体 積分率では CUが最も大きく, 次いでRPE,WPE, PTT の順 である。ポリエステル系試料の有効熱伝導率の間に有意差は 認められなかった。

（6）試料の厚さが減少することにより，有効熱伝導率のレ ベルが低下するとともに，曲線形状が平坦化して繊維素材の 特徵が薄れ，繊維素材間の差が小さくなる.

以上, 試料一測定系への熱の流入の排除および試料枠側面 からの熱のもれに配慮しつつ，低体積分率における短繊維集 合体の有効熱伝導率の測定を行った. 非線形回帰分析により, 結果を解析し, 有効熱伝導率の測定值を, 繊維伝導成分, 輻
射成分，ガス伝導成分および試料枠側面からの漏れ成分に分 離することができた。このうち，纎維集合体における保温性 の実現には, 瀻維集合構造による不動空気の形成が最も重要 な要因であることが示された。これに次いで, 繊維伝導成分 が，比較的大きな繊維体積分率の範囲で寄与が大きい. 保温 性素材としての繊維素材の特徵は, 繊維伝導成分の係数 A の 大小という形で現れている。ここに，単繊維の熱伝導率に関 する知見が必要である $[11]$ ，輻射成分の寄与は，本測定で採 用したランダム配向繊維集合体の場合，無視できるほど小さ い. 熱の漏れ量を精度よく校正するためには，ガス伝導成分 $\mathrm{C}$ の測定精度が重要である。以上の知見は, 保温性の実現を 目的とした低い体積分率の繊維集合体の材料設計にあたって 基礎的な情報となる。

\section{謝 辞}

本研究の遂行に際し, 奈良女子大学生活環境学部学生（当 時）川原幸乃氏の多大なる協力をいただきました。ここに記 して謝意を表します。

\section{References}

[1] Nogai T (1980) Sen'i Gakkaishi, 36, 389-396

[2] Nogai T, Ihara M (1980) Sen'i Gakkaishi, 36, 427-434

[3] Fujimoto T, Niwa M (1989) J Text Mach Soc Japan (predecessor journal of J Text Eng), 42, 27-35

[4] Kawabata S (1984) J Text Mach Soc Japan (predecessor journal of J Text Eng), 37, 130-138

[5] Ohmura T, Tsuboi M, Onodera M, Tomimura T (2002) Proceedings of the Institute for Functional Material Science (Kyusyu University), 16, 13-17

[6] Rennex B, Somers T (1985) Journal of Buildings Physics, 8, 175-197

[7] Symons JG, Clarke RE, Peirce JV (1995) J Thermal Insul and Bldg Envs, 19,72-88

[8] Campanale M, Moro L (1997) J Thermal Insul and Bldg Envs, 21, 153-170

[9] Japan Society of Thermophysical Properties Ed. (1990) “Thermophysical Properties Handbook", p.59, Yokendo Pub.

[10] Ibid., p.178

[11] Kawabata S (1986) J Text Mach Soc Japan (predecessor journal of J Text Eng), 39, 184-186

\section{付録 非線形回帰モデル}

本研究で取り扱っている繊維集合体の空隙率は非常に大き いため, 集合体内部での熱移動の形態には繊維の熱伝導に加 えて, 空隙に関わる効果が強く現れているものと考えられる. すなわち, 纎維中の熱伝導, 繊維間空隙内での輻射伝熱, お よび，空隙中の気体（空気）を介した熱伝導からなるものと 考えられる。これら 3 つ伝熱要素が熱流に対して並列に配 置されていると仮定する（並列モデル）と，有効熱伝導率の 
測定值 $\lambda(\mathrm{W} / \mathrm{mK})$ は嵩密度 $\rho\left(\right.$ bulk density, $\left.\mathrm{kg} / \mathrm{m}^{3}\right)$ の関数とし て, 3 つの要素の和で表される [5].

$$
\begin{aligned}
\lambda & =\lambda_{c}+\lambda_{r}+\lambda_{g} \\
& =A \rho+B / \rho+C
\end{aligned}
$$

ここで， $\lambda_{\mathrm{c}}$ は緘維の等価熱伝導率， $\lambda_{\mathrm{r}}$ は輻射伝熱に関する 等価熱伝導率, $\lambda_{\mathrm{g}}$ は気体の等価熱伝導率, $\mathrm{A}\left(\mathrm{Wm}^{2} / \mathrm{Kkg}\right), \mathrm{B}$ $\left(\mathrm{Wkg} / \mathrm{m}^{4} \mathrm{~K}\right)$ は係数, $\mathrm{C}(\mathrm{W} / \mathrm{mK})$ は定数である. (A1b) 式第 1 項は繊維中の伝導伝熱項, 第 2 項は繊維間空隙内の輻射伝熱 項, 第 3 項は空隙中の気体を介した伝導伝熱項を表している. パラメー夕 A, B, Cの物理的意味について, 文献 [5]の記述 をもとにして本研究における状況を加味して以下に要約す る.

\section{(a) 繊維中の熱伝導}

繊維集合体中の繊維を介した熱移動に関連する要因として は, 単位体積あたりの繊維の本数, 繊維一繊維間接触点数な どが考えられる。これらの要因は嵩密度が大きいほど大きく なるものと考えられる。簡単化のためこれを比例関係とする と, 繊維による伝導伝熱に等価な熱伝導率 $\lambda_{\mathrm{c}}$ は係数 $\mathrm{A}$ を用 いて次のように表される.

$$
\lambda_{c}=A \rho
$$

(b) 繊維間空隙における輻射伝熱

繊維集合体内の空隙における輻射伝熱成分に等価な熱伝導 率 $\lambda_{\mathrm{r}}$ は次式で表される.

$$
\lambda_{r}=4 C_{0} d \sigma \varepsilon T^{3}
$$

ここで, $\mathrm{C}_{0}$ : 係数 (n.d.), d: 平行平板間の距離 $(\mathrm{m}), \sigma$ : 久 テファン・ボルツマン定数 $\left(\mathrm{W} / \mathrm{m}^{2} \mathrm{~K}^{4}\right), \varepsilon$ ：輻射率 (n.d.), $\mathrm{T}$ : 絶対温度 $(\mathrm{K})$ である. 測定セル内に充填する纎維集合体試料 の質量を $\mathrm{M}$, 断面積を $\mathrm{S}$ とすると $\mathrm{d}=\mathrm{M} / \mathrm{S} \rho$ で表される。これ を式 (A3) に代入すると,

$$
\begin{aligned}
& \lambda_{r}=4 C_{0} \frac{M}{S \rho} \sigma \varepsilon T^{3}=\frac{B}{\rho} \\
& B=4 C_{0} \frac{M}{S} \sigma \varepsilon T^{3}
\end{aligned}
$$

となる。野飼ら $[1,2]$ は, 繊維集合体内部の熱伝達に対する 輻射成分の寄与を次の 4 つの要素に分けている。すなわち,
（1）熱源－繊維間，（2）熱源－ヒートシンク間，（3）繊維 纎維間, (4) 繊維一ヒートシンク間. このうち, 式 (A3) で 表されているのは，(2)の熱源一ヒートシンク間の輻射熱伝 達であると考えられる。

(c) 空隙中の気体を介した伝導伝熱

第 3 項の $\mathrm{C}(\mathrm{W} / \mathrm{mK})$ について検討する。本実験で用いてい る空隙のサイズは大気圧下における空気の平均自由行程 L と 比較してはるかに大きいことが確認されている。したがって, 空隙率の変化により自然対流が発生するかどうかについて検 討しておく必要がある.

繊維集合体内での自然対流の発生の検討には, 次式の通常 のレイリー数に対して繊維集合体における形状因子を付け加 えた修正レイリー数 [10]を用いる.

$$
R a=\frac{g \beta \Delta \theta d^{3}}{v \kappa} \frac{k}{d^{2}}
$$

ここで, $\mathrm{g}\left(\mathrm{m} / \mathrm{s}^{2}\right)$ は重力加速度 $\left(=9.8 \mathrm{~m} / \mathrm{s}^{2}\right), \quad \beta(1 / \mathrm{K})$ は空 気の体膨張係数, $\Delta \theta(\mathrm{K})$ は熱源とヒートシンクの温度差, $\mathrm{d}$ (m) は試料の厚さ, $v\left(\mathrm{~m}^{2} / \mathrm{s}\right)$ は空気の動粘性係数, $\kappa\left(\mathrm{m}^{2} / \mathrm{s}\right)$ は 空気の熱拡散率である。また, $\mathrm{k}\left(\mathrm{m}^{2}\right)$ は Darcyの透過率で, 繊維集合体における繊維径 $\mathrm{t}(\mathrm{m})$ と空隙率 $\phi$ (n.d.) に依存し た形状因子である。これは次式で表される.

$$
k=\frac{t^{2} \varphi^{3}}{122(1-\varphi)^{2}}
$$

以上から， $\operatorname{Ra}$ が臨界修正レイリー数 $\operatorname{Racr}(=39.5)$ より大きく なると, 繊維集合体内で自然対流が発生することになる.

たとえば, RPEの体積分率 0.03 の場合で考えた時, 温度 が $25^{\circ} \mathrm{C}$, 繊維径 $\mathrm{t}$ が $1.276 \times 10^{-5} \mathrm{~m}$, 空隙率 $\phi$ が 0.97 , 重力加 速度 $\mathrm{g}$ が $9.8 \mathrm{~m} / \mathrm{s}^{2}$, 空気の膨張係数 $\beta$ が $1 / 373(1 / \mathrm{K})$, BT-Box と冷却ベースの温度差 $\Delta \theta$ が $10 \mathrm{~K}$, 試料の厚さ $\mathrm{d}$ が $0.02 \mathrm{~m}$, $0.03 \mathrm{~m}, 0.05 \mathrm{~m}$ の 3 条件, 空気の動粘性係数 $v$ を $1.579 \times$ $10^{-5} \mathrm{~m}^{2} / \mathrm{s}$, 空気の熱拡散率 $\kappa$ を $2.215 \times 10^{-5} \mathrm{~m}^{2} / \mathrm{s}$ とすると,

$\begin{array}{ll}d=0.02 & R a=0.0202 \\ d=0.03 & R a=0.0304 \\ d=0.05 & R a=0.0513\end{array}$

を得る。したがって, $\operatorname{Ra}<\operatorname{Racr}(=39.5)$ となり, 纎維集合体内 では自然対流は発生しないことから，Cは定数であり， $\lambda_{\mathrm{g}}=$ Cと考えられる。これをガス伝導成分と呼ぶことにする。 